LÚCIA RICOTTA V. PEDRAS

\title{
A paisagem em
}

\section{Alexander von Humboldt:}

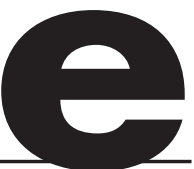

m 1808, quatro anos depois de viajar pelo Novo Mundo, Alexander von Humboldt (1769-1859) publicou na Alemanha e na França Quadros da Natureza (Ansichten der Natur e Tableaux de la Nature). O relato da expedição, tarefa inerente às viagens naquela época, seria o primeiro trabalho a ser publicado, se não fosse o gigantesco volume de informações e materiais de pesquisa coletados por Humboldt e Aimé Bonpland na América. Os cientistas optaram pelo primado enciclopédico, lançando a obra americanista de 30 volumes em edição monumental infolio e in quarto. Sob o título geral de Voyage aux Régions Équinoxiales au Nouveau Continent, fait en 1799, 1800, 1801, 1802, 1803 et 1804 , o relato contou com o apoio financeiro do rei da França e levou pouco mais de 25 anos para completar a edição dos quatorze títulos que a compõe.

Quadros da Natureza desta forma constituiu, ainda com independência relativa em relação ao relato do Novo Mundo, uma tentativa de experimentar até que ponto as cenas da natureza, dos diversos continentes, podiam ser descritas sem perder o efeito do natural e sem perder a força de evocação e a consistência material de um juízo perceptivo sobre a natureza.

A leitura deste livro procurava sugerir ao leitor do século XIX o cultivo simultaneamente estético e científico das cenas naturais. Com efeito, a união de arte e ciência vinha a ser essencial para sua qualifica-

\section{o modo}

\section{descritivo dos}

\section{quadros da}

\section{natureza}

ção literária. Simples “apresentações vivas" (lebendige Darstellungen), com mapas e representações pictóricas de plantas, animais que não só visam a aumentar o "gosto pela natureza" (Naturgenus) quanto a ampliar o "estado da ciência" (Stande der Wissenschaft), os “quadros da natureza” de Humboldt propõem uma ligação (Verbindung) entre as finalidades científica e literária, que não estava comumente associada ao processo de individuação das disciplinas no século XIX. Numa apresentação sumária, tratava-se de uma série de trabalhos que nasceram "em presença dos grandes objetos da natureza (im Angesicht grosser Naturgegenstände), sobre o oceano, no meio das florestas do Orenoco e das estepes da Venezuela, nas montanhas de-
LÚCIA RICOTTA V. PEDRAS é doutoranda em História Social da Cultura na PUC-Rio. 
Alexander von Humbold (1808), "Vorrede zur ersten Ausgabe", in Ansichten de Natur Greno Franz, Nördlingen, 1986, p. 9. sertas do Peru e do México" (1). Em todas as cenas, há um ponto intrínseco que garante um alto grau de coesão à diversidade de recortes e que é retomado sempre que se junta, à observação das propriedades físicas da paisagem, o esforço de reproduzir a “imagem refletida na imaginação e no pensamento" do homem. A dupla perspectiva de Quadros da Natureza é o evento crucial porque cumpre função estrita no conjunto: a interação entre literatura e ciência, ou entre sentimento e idéia, é o fato decisivo, a ser acompanhado em suas múltiplas caracterizações, uma vez que o literário vai funcionar como matéria complementar e compensatória do discurso da ciência.

A transparência da linguagem e, sobretudo, de sua força mimética no modo descritivo de apresentação dos textos foi utilizada de maneira a não se chocar com a imagem que o viajante via e experimentava no contato direto com a natureza. $\mathrm{Na}$ avaliação de Humboldt, o leitor era assim levado a ver quase com seus próprios olhos.

Ao traço descritivo que assegura a emergência de uma imagem exata logo corresponde outro que transforma essa imagem em “apresentação viva". A realidade objetiva é uma pergunta recorrente, cumprida, aliás, no próprio ato de olhar as cenas da natureza. A paisagem de Humboldt é o exercício constante de uma mente curiosa que tenta, enfaticamente, se aproximar ao encontro do novo. As construções dos quadros remetem sempre à realidade físico-

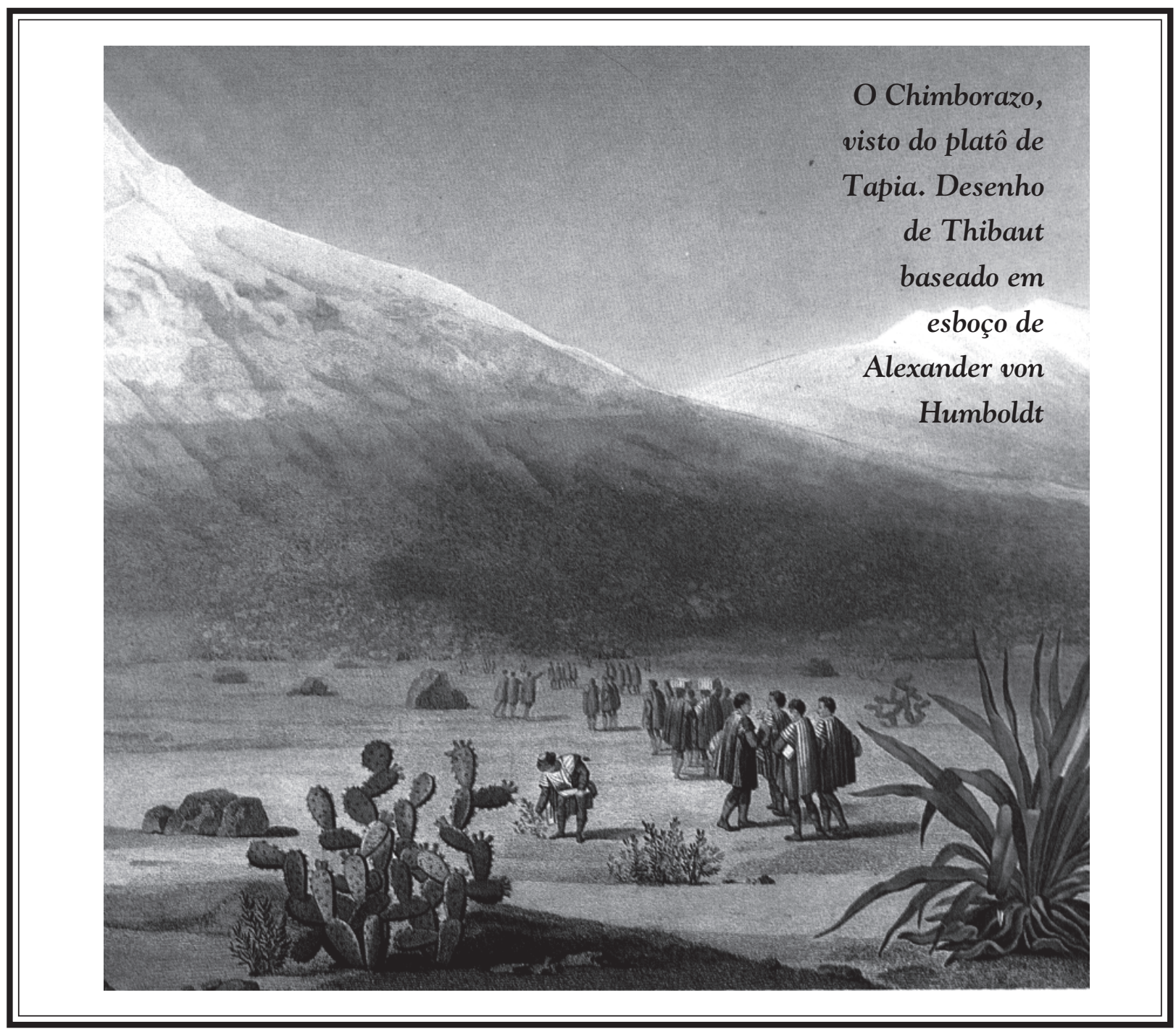


espacial. Uma poética da introspecção se viabiliza mediante o processo de conversão mimética da realidade numa realidade visível, paisagística, mas, sobretudo, só um "quadro", rigorosamente descrito, coloca, acima do cultivo estético da natureza, a dimensão cognitiva que a beleza dos "países tropicais" (Tropenländer) veio a tomar aos olhos dos europeus nesse século XIX.

A conquista da paisagem do Novo Mundo, que pressupõe uma mímesis naturalista, propicia não tanto o fluxo livre da imaginação quanto a evocação reveladora da experiência do espaço. Para além da surpresa de engendrar sensações apaziguadoras, o importante é repor o sentido do ato de olhar a natureza. O que não se resolve abandonando a perspectiva do cultivo espiritual através do contato com o mundo objetivo. Sintomaticamente, todo o modo de apreciação estético humboldtiano retoma o "gosto da natureza" provocado pelo livre contato, o que por certo implica reavaliar a base descritiva-topográfica que informa e qualifica a percepção visual do viajante em cenário até então não descrito com tanta literalidade.

Afastando-se da orientação que considera o descritivo um primo pobre da poética literária e da teoria, os quadros da natureza de Alexander von Humboldt se aproximariam do tipo dominante artístico e literário que apela antes de tudo para o visual. Seu recorte pictórico evoca primariamente o mundo visualizado e experimentado pelo viajante. A precisão descritiva, em seus delineamentos gráficos, junto com a ambigüidade perceptiva, revelada no contato direto, aliam-se aqui para engendrar uma paisagem a sugerir uma imagem viva. Espécie de figuração que expõe com detalhes concretos a informação visual.

\section{VER, CONHECER E REPRESENTAR}

Operar na direção do olhar que se eleva à condição de imperativo poético e cognitivo pressupõe a capacidade de assimilar a densidade da história. Embora o viajante procu- re se despir de suas expectativas para penetrar num espaço, cujas marcas de cultura ainda são incipientes e rudimentares, arriscaríamos dizer que no momento mesmo em que o viajante visualiza uma cena da natureza, os quadros da natureza já trazem uma história (e até, graças à tríade harmônica existente entre o ver, o conhecer e representar, uma imagem de infinitude poética ligada ao saber de sua origem).

Ao tentar rastear as imagens de paisagem que vão se formando ao longo de Quadros, meu propósito é o de trazer à luz os fundamentos de um saber descritivo e método de conhecimento, cuja força reside, simultaneamente, no poder de evocação e atestação da imagem visual. Saber e método que, ainda que ganhem considerável veemência com sua prática e instrumentalização técnica a objetivar o olhar do cientista, não se restringem à objetividade pura, que atesta e documentaliza, pois a imagem viva dos quadros da natureza de Humboldt acolhe ainda um dado imaterial importantíssimo através do movimento de espacialização da sensação do viajante.

Isto quer dizer que o saber descritivo e a prática da descrição não irão constituir os únicos fundamentos da concepção de ciência humboldtiana. Eles, sem dúvida, estarão presentes como forma e técnica de conhecimento, mas não de maneira dominante e/ou determinante.

O decisivo na ciência de Humboldt é a intersecção estabelecida entre dois modelos científicos: o modelo da descrição e o da especulação. Para que tal conduta se explicite tentaremos verificar, nas partes descritivas da paisagem tropical em Quadros, qual o peso da imagem visual frente ao impulso especulativo do cientista que insiste em radicar no contato direto com a paisagem. Só assim estaremos aptos a manejar um dos componentes estruturais da construção da paisagem americana em Humboldt, tomando-os como resultantes de uma operação que, mesmo centrada na observação empírica, é capaz de (des)automatizar um dado último do real.

Onde a forma de conhecer é a medição fiel da realidade reproduzida em "quadros", 
2 Ao tratarmos da noção de re presentação pictórica na pa sagem humboldtiana, queremos verificar de que forma articulação harmônica entre arte e ciência, proposta por Humboldt, tem na descrição uma das suas bases estruturais. E, vale dizer, que a descrição como forma de acesso a essa articulação, ganhava legitim dade porque era tomada não só como forma de conhecer, mas também enquanto técnica método de conhecimento científico no século XIX. E isso pode ser um dado específico do ide al harmônico presente em Humboldt - esse intercâmbio entre teoria e técnica desde que a instrumentalização doconhecimento teórico nunc inviabilizasse o especulativo.

3 J. W. Goethe (1798) "Empirical Observation and Science", in Collected Works, vol. 12-Scientific Studies, pp. 24 e 25. Goethe, preocupado em definir a experiência do conhecimento científico, enume ra suas três fases constitutivas: "1. O fenômeno empírico que qualquer um acha na natureza e que é depois através de experimentos elevado ao segundo nível. 2. O fenômeno científico produzido sob circunstâncias e condições diferentes da quais ele foi primeiramente ob servado, enuma seqüência que é mais ou menos produtiva. 3 . O fenômeno puro aparece en nossa frente como o resultado de todas nossas observações e experimentos. Ele nunca pode ser isolado, mas aparece numa contínua seqüência de eventos. Para pintá-lo, a mente humana dá definição ao empiricamente variável, exclui o acidental, coloca de lado o impuro, des faz o complicado, e sempre descobre o desconhecido".

4 Humboldt (1808), Ansischten der Natur, mit wissenchaftlichen Erläuterungen, trad. de Assis Carvalho, Quadros da Nature $z a$, Rio de Janeiro, São Paulo Porto Alegre, W. M. Jackson, vol. 1, p. 335: "A pintura de paisagem também não é puramente imitativa; tem, contudo fundamento mais material e há nela um tanto de terrestre. Ex ge dos sentidos uma variedade intinita de observações imediatas, que o espírito deve assim lar para as fecundar com o se poder, e dá-las aos sentidos sob a forma de uma obra de arte"

5 Svetlana Alpers (1983), The Art of Describing. Ducth Art in the Seventeenth Century, The University of Chicago Press, 1984. A perspectiva adotada pela autora procura desvincular a representação pictórica modo descritivo - da arte ho landesa do XVII do modelo re- a ênfase da experiência cognitiva recai sobre o discernimento do olhar para transformar as imagens visualizadas junto ao natural em imagem fotografada junto à escrita do livro. Tratar da representação pictórica nessas descrições naturalistas pode garantir o exame sobre a força de coesão da descrição, eis em que se sustenta nossa proposta - a descrição funcionando ora como técnica perceptiva e pictórica, ora como meio científico a articular o fenômeno visual. Isto equivale a dizer que, no interior do ideal humboldtiano, o papel do descritivo não vai se restringir a uma forma teórico-explicativa de conhecer (e lembre-se aí a sentença expressa no Cosmo - "a descrição do mundo é a explicação do mundo"), mas vai se estender paralelamente a uma arte de ver, divulgar e representar pictoricamente a imagem visual.

Talvez devêssemos nos aproximar de determinado modelo de ciência do XIX para verificar até que ponto é exato supor o apelo à descrição por Humboldt como a sua forma de descobrir os limites teórico e técnico (2) da percepção humana (que, em última instância, iriam constituir os limites de arte e ciência).

A consolidação da ciência no Oitocentos alemão previa os esforços prático e especulativo (3) na forma de aproximação com o fenômeno. A “observação empírica”, preocupada em extrair "o aspecto individual do fenômeno", persegue a aparência do fato - "não só como o fenômeno aparece mas como ele deveria aparecer". A mobilidade dessa aparência seria o elemento capital se sua mutabilidade não fosse percebida e premeditada. O problema básico então parece de fácil formulação: conciliar o percebido e o premeditado, isto é, a aparência e seu significado ideal, de modo a tornar simultâneo e idêntico o resultado das duas apreensões díspares. O fato empiricamente visualizadoé submetido a "elevado" ponto de vista. Procura-se extrair da distribuição diversa das formas naturais determinada “constância e consistência" até derivar uma "lei empírica" capaz de explicar as condições sob as quais o fenômeno se manifesta.
A construção da paisagem em Humboldt obedece rigorosamente ao processo de conhecimento descrito acima. Supõe-se o duplo percurso da observação científica incidindo sobre o estatuto da paisagem humboldtiana e convertendo-a na mesma prévia duplicidade. Termina por formar o caráter e revelar o destino de dois tipos recorrentes de paisagem em Quadros: a paisagem, transcrição exata da imagem visualizada no contato direto junto à natureza, e a paisagem que, embora programada pelo cálculo exato e pontual, vai ser manipulada e reconstruída a fim de atingir uma paisagem ideal (4).

Paisagem ideal é exatamente aquela que figura um conteúdo pré-dado e consome a aparência na medida mesma em que esta sirva de conduto para a dedução de leis frente à diversidade de elementos naturais. Nada há de contraditório em Humboldt, ao se delinear juntamente à paisagem ideal a paisagem representada num modo descritivo, em que, para usar definição da historiadora de arte Svetlana Alpers, “[...] ]o significado [da imagem] encontra-se pela sua própria natureza naquilo que o olho é capaz de captar"'(5).

Entretanto, sem muito alarde, à maneira de um desafio, cumpre sublinhar a relativa importância adquirida pela paisagem enquanto "arte de descrever", entendendoa menos como indício de um sentido profundo e mais como "modo pictórico [... descritivo" que se apóia no fenômeno visual. Com isso, não queremos descartar a culminância ainda muito viva do espiritual nesse fraternal encontro do homem com a natureza, mas apenas afrouxar sua carga subjetivadora que poderia nos impedir de invocar a intenção de objetividade e de atentar para a tensão no intercâmbio entre mundo interno e mundo exterior. Esse nosso esforço visa a confrontar o entendimento da paisagem como resultado puro e simples de uma construção mental com a idéia de que a paisagem vinha sendo construída também via descrições do encontro com o real, via descrição daquilo que se apresentava à vista. Desse modo, o estatuto da descrição em Humboldt é válido não só 
como forma de conhecimento - limitada pela especulação -, mas também como técnica de representar o mais fielmente possível a realidade captada pelo olhar e pela imaginação.

Representar o mais fielmente possível, em Humboldt, não significa que a descrição trabalhe em favor do extravio da emoção e, portanto, em prol da documentação neutra, pois é justamente o contato direto e a presença do viajante junto à natureza que lhe sugerem uma amplitude de acesso à ordem do sensível. Aí, o que resulta novoé o aparecimento de uma articulação diversa da imagem, em que a descrição, sendo registro material de conhecer e representar o fenômeno visual captado no contato direto, inclui um dado de notória importância: a sensibilidade do observador. O que repõe, por sua vez, o valor adquirido pela instantaneidade do olhar dentro desse modo técnico e cognitivo da descrição, ao fazer do fato imediato, da paisagem vivenciada e coletada, princípio para sistematicidade, produção e conhecimento das imagens desse novo cenário americano. O que se vê e o que se sente constituem aqui atributos mensuráveis a serem transmitidos pela descrição.

Pondo de lado essas considerações, não se pode negar a importância para este texto da linha explorada por Svetlana Alpers em seu Arte de Descrever (Art of Describing).

A autora procura, nos aspectos centrais da arte holandesa do século XVII - para ela, uma forma pictórica essencialmente descritiva -, elementos pictóricos e historicamente distintos da arte narrativa italiana. Ao partir da reflexão de Svetlana Alpers, não se pretende afirmar a influência dos pintores holandeses sobre a paisagem de Humboldt, muito menos sobre o que se denomina a pintura realista do XIX, mas antes identificar, num modo particular de pintura trabalhado pela autora, as ferramentas para se tratar da natureza paisagística em Humboldt.

Só uma paisagem livremente engajada na predominância de uma forma específica, a imagem viva - que devia ser o próprio natural na forma de "quadro" -, coloca, acima da diversidade natural, o efeito de surpresa causado pela percepção visual. A série de linhas descritivas começa justamente por divulgar e evocar a sensação da presença. A imagem esboçada pictoricamente depende da forma material como se conhece e como se vê quando a exposição decididamente frontal permite atestar. Pois é verdade, a atenção e a sensibilidade do artista estão permanentemente expostas a mudanças de luz e cor que influenciam não só o conhecimento do real mas o processo de feitura da imagem e do "quadro" portanto. Nesse sentido, a meu ver, os quadros da natureza delineados por Humboldt pressuporão menos uma leitura interpretativa do que a evocação e a produção de imagens agindo como suportes da realidade sensível apresentada à vista.

O interessante de investigar é esse processo científico de definição da paisagem. Ao menos neste caso, embora o interesse científico e a arte de descrever em campos opostos e paralelos se mantenham, a estabilidade dos dois é de igual natureza. Ambos têm a limitação de só conseguirem operar na transparência. Isto exige do naturalista um trabalho de depuração do natural e de seus elementos sensíveis para reprodução, de forma a ser possível considerar a paisagem descrita uma composição híbrida que mistura o apego da técnica descritiva ao panorama visualizado e o conhecimento prévio das leis naturais. Bem característico da concepção estética humboldtiana, o critério de obra de arte para a representação descritivo-pictórica dos quadros está contraditoriamente aferrado à máxima capacidade óptica da percepção do cientista e à idealização conceitual da paisagem. Paisagem concreta-natural e paisagem ideal vão ambas tencionar a proximidade entre imagem-técnica e imagem-conceito. A paisagem só vai ser artisticamente legitimada quando preservar a vivacidade, a proporção exata da forma, o colorido do natural.

Com isso não quero afirmar que o paradigma da ciência, seguido por Humboldt, descarte a leitura dos dados que estão além do sensível ou de sua aparência. Para nascentista de pintura maises pecificamente da definição de Alberti para a pintura. "Italian art and the rhetorical evocation of it has not only defined the practice of the central tradition of Western artists, it has also determined the study of their works. In referring to the notion of art in the Italian Ranaissance, have in mind the Albertion definition of picture: a framed surface or pane situated at a certain distance from viewer wholooks through itata second or substitute world. In the Renaissance this world was a stage on which human figures performed significant actions based on the texts of the poets. It is a narrative art. And the ubiquitous doctrine ut pictura poesis was invoked in order to explain and legitimize images through their relationship to prior and hallowed texts [...] major theme of this book is that central aspects of seventeenthcentury Dutch art - and indeed of the northern tradition of whic it is part - can be best understood as being an art of describing as distinguished from the narrative art of Italy". 
6 Humboldt (1845-1862) Kosmos. Entwurf einer physischen Weltbeschreibung rad de M. H. Faye e M. C. egrand: Cosmo Essai d'une Description Physique du Monde, Paris, Pomey et Crouzet Libraries-Editeurs, s. d. vol.3, p. 9. Podemos perceber que os princípios orientadores da at tude científica de Humbola stão muito próximos dos pressupostos científicos de Goethe: O princípio fundamental de meu livro [...] é a tendência constante a recompor a partir dos fenômenos o conjunto da atureza, a mostrar nos grupos isolados desses tenômenos as condições que lhe são comuns isto é, as grandes leis que re gem o mundo; enfim, a fazer ver como a partir do conhecmento dessas leis remontamos a ligação de causalidade que os une uns aos outros. Para conseguir revelar o plano do mundo e a ordem da natureza, preciso começar por genera zar os fatos particulares, procurar as condições nas quais as mudanças fisicas se reprodu zem de maneira uniforme. Assim, somos conduzidos a uma contemplação racional dos materiais fornecidos pelo empirismo, e não a visões puramente especulativas, a um de senvolvimento abstrato do pensamento, a uma idéia absoluta independente da experiência"

7 Correspondência de Capis trano de Abreu, Rio de Janeiro Instituto Nacional do Livro, 1954, p. 34. "Carta de Capistrano de Abreu a João Lúcio de Azevedo, s. d. E interessante ver como o relato de viagem e a descrição científica de Humboldt - que mistura re lato de viagem, descrição e re presentação pictórica, discurso científico - são tomados como roteiros de visitas, como as próprias visitas e como 'ar quivo de informações de lugares até então desconhecidos, mas que despertam grande curiosidade". Vejamos alguns comentários de Capistrano com relação a Viagem pelo Brasil relação a Viagem " pelo Brasil melhor cicerone que o terceiro volume de Martius", p. 34 . Em outra carta ao mesmo remeten te o entusiasmo de poder faze uma viagem acompanhado do olhar do estrangeiro parece ser decisivo: "E vai agora fazer a viagem com Martius! Que livro admirável, que esplêndido companheiro", p. 78

8 Consideremos a instigante passagem do prefácio de Doutrinas das Cores de Goethe para entendermos o significado de estímulo, de prazer que esse saber técnico estetizado, a iteratura - descrição pormenor zada dos fenômenos naturais -
Humboldt ou para um cientista de sua época, a natureza é também um livro, cuja legibilidade resulta necessariamente da exploração de uma "tendência única" - de uma legislação - sobre todas as forças vitais (6). Antes de sua postura abstrata diante da natureza, existe nele uma preocupação em tornar os caracteres da paisagem reprodutíveis, visíveis, e é isso que explica o papel central dado à descrição enquanto meio que organiza a perpetuidade da impressão estética. Mesmo que a investigação humboldtiana se mantenha largamente comprometida com uma leitura divinatória da natureza, ela guarda em si potencialidades de desenvolvimento em sentido estritamente científico do século XIX, onde a preocupação com a descrição física constitui um dos pilares dessa ciência.

Ora, tendo visto como a composição dos quadros da natureza de Humboldt distingue, entre as virtudes mais abstratas do olhar, o gosto pelo lance topográfico e descritivo, não se pode identificar os traços da paisagem humboldtiana sem antes determinar as trilhas percorridas e os caminhos adotados pela vista do viajante. Vamos esquadrinhar as imagens comunicadas pelos quadros através de um roteiro do olhar - o olhar de Humboldt -, cuja direção segue a visualização de cenas pitorescas vislumbradas junto ao solo natural e/ou compostas aprioristicamente. Tentarei oferecer um desenho do movimento de penetração do olhar do viajante naturalista.

\section{RELATO E DESCRIÇÃO:}

\section{A LITERATURA COMO “MELHOR CICERONE" (7)}

A obsessão do viajante cientista pela transposição de cenários justifica muitas vezes o uso que aqui se faz da literatura o de torná-la não só descritiva e documentalista mas compensatória de prazer diante do esforço especulativo e da auto-reflexão.
O conhecimento e o domínio do novo espaço dependem em larga escala da descrição do novo terreno, efetuada a partir de uma escrita calculada, medida e ajustada ao que se está vendo. A literatura é decifratória, porque funde os detalhes mínimos desse novo panorama avistado numa unidade sintetizadora da ciência. Elaé também plástica, fotográfica, porque vira superfície refletora e reprodutora de cada canto do cenário que se descortina. A literatura em quadros ou a representação pictórica da paisagem, para Humboldt, vai, portanto, se constituir em mapa, numa representação gráfica compilada, de onde resultam, por meio do traçado de linhas e pontos coloridos, as regiões ainda desconhecidas. Mas, além de oferecer dados concretos para o conhecimento científico daquela natureza exótica, ela é evocatória, pois dá aos que a lêem alguma qualidade do lugar e da sensação experimentada pelo observador na América (8).

Tomando novamente o argumento de Svetlana Alpers sobre o estatuto da imagem visual na pintura holandesa do século XVII, temos condições de identificar o compromisso da literatura em "pintar" a terra americana. Cabia ao registro literário e científico, encarnado pelos relatos oitocentistas, a eficácia para "fazer ver" imagens do desconhecido. O exercício consciente desse sentido dos "quadros" assinala a relação de "semelhança" entre pintura e mapa que, por sua vez, encontrou condições para se impor e desenvolver, segundo Svetlana Alpers, a partir do século XVII, com o surgimento de uma confluência entre representação cartográfica e modo de fazer imagens. Ao dispor no mapa de medidas de um lugar, dados quantificáveis, ou, em outras palavras, da base cognitiva do contexto do mapa, a arte holandesa expressava não só uma existência de fato, mas a qualidade de um lugar ou da sensação experimentada pelo observador. $\mathrm{O}$ que remete à forte presença pictórica do mapa, a tal ponto em que este vai se constituir, segundo a autora, em modelo para a "feitura, visão e entendimento das imagens"(9): 


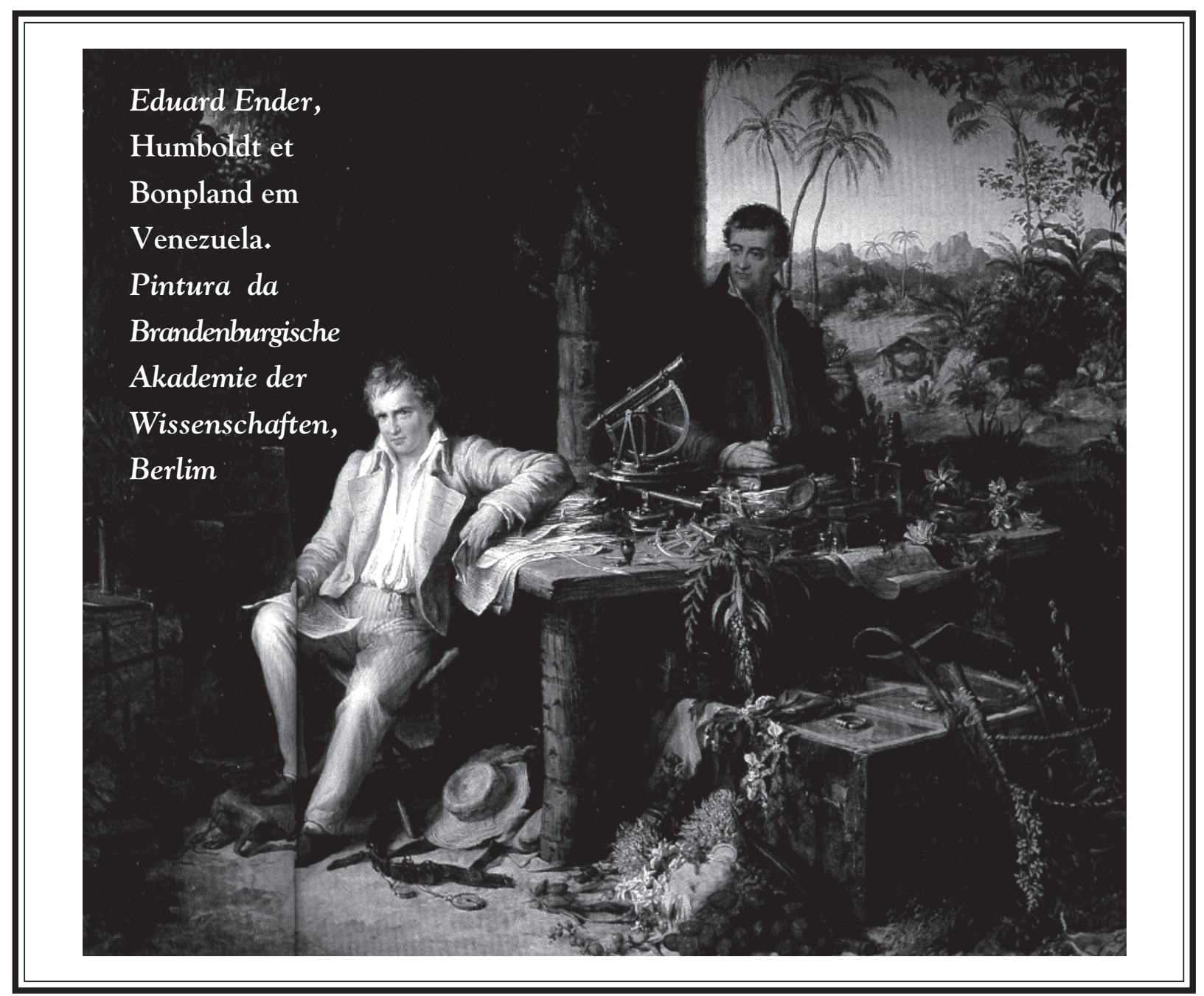

"Se [o] mapa é apresentado como uma pintura, a que noção de pintura ele corresponde? Vermeer sugere uma resposta a essa questão na forma da palavra Descriptio [...] Este era um dos termos mais usados para designar o trabalho de representar mapas. Os feitores de mapas ou publicistas eram tomados como 'aqueles que descreviam o mundo' e seus mapas ou atlas como o próprio mundo descrito. Embora, tanto quanto eu saiba, este termo nunca tenha sido aplicado à pintura, existe agora um bom motivo para sê-lo. O objetivo dos pintores holandeses era o de capturar numa superfície uma grande diversidade de conhecimento e informação sobre o mundo. Eles também usavam palavras com suas imagens. Assim como os feitores dos mapas, os pintores faziam trabalhos aditivos que não poderi- am ser tomados de um único ponto de vista. Seus trabalhos não eram uma janela tal qual no modelo italiano de arte, mas, ao invés, um mapa, uma superfície na qual se dispunha um conjunto unificado do mundo"(10).

Humboldt, a meu ver, está plenamente engajado nessa "arte de descrever" pois parece compenetrado em um estilo direto e simples em favor de traços pictóricos herdeiros de delineamentos gráficos próprios à composição de mapas. Seguindo a tradição do modo descritivo pictórico holandês, não interrompido através do século XVIII, Humboldt guardara dessa tradição, cujo gosto exaltava, justamente as formas menos incompatíveis com a sensibilidade ora triunfante: os quadros da natureza americana reunindo em si qualidades opostas deveria ter para o leitor interes sado em experimentar a bele za da natureza como se estivesse ao "ar livre": "Para que seja aproveitada e desfrutada a natureza deve se apresenta realmente ou por meio de viva fantasia ao leitor. $\mathrm{Na}$ verda de, o escritor deve falar e apre sentar os fenômenos aos ou vintes como num texto em que uma parte deles vem até nó sem que os busquemos, en quanto a outra parte pode ser vista mediante dispositivo deliberadamente construídos para essefim; só então comentários, interpretações e esclo recimentos produzirão um vivo efeito". Cf. Goethe (1940) Farbenlehre: tradução seleção e apresentação de Marco Gianotti, Doutrina das Cores Nova Alexandria, São Paulo 1993, p. 41

9 S. Alpers (1983), op. cit. Ver especialmente o trecho em que a autora ana lisa um quadro de Vermeer - The Art of Paintin, ct. pp. 119-26.

10 ldem, p. 122 
podiam ser diretos e descritivos, nem por isso deixavam de ser ideais e abstratos. São dessa espécie os "quadros" que constituem as imagens e os mapas pictóricos de Humboldt sobre a América. Por sua forma, iluminam-se alguns dos traços mais significativos dessa arte de descrever que se detém na superfície, no concreto e no espaço, e por isso mais facilmente se presta à "melhor cicerone" aos leitores interessados em incorporar o olhar do estrangeiro e a outros viajantes interessados em percorrer terras até então desconhecidas, isto é, não descritas, não mapeadas e, portanto, não visitadas.

Isto significava tanto que o olhar do naturalista era privilegiado por desfrutar do contato direto com o novo, como também que esse privilégio se estendia àqueles que liam-e, imediatamente, visualizavam - as cenas contempladas pelo viajante e acompanhavam a contemplação minuciosa dos tesouros da “zona tórrida”. A viagem ao Novo Mundo não só satisfazia a avidez de experimentar - sensivelmente, diretamente - o novo que só se torna conhecido, pelo europeu, quando encerrado na moldura fixa da ciência; mas também propiciava ao cientista a oportunidade de classificar, identificar e comparar a heterogeneidade da vegetação dos trópicos à paisagem homogênea da Europa.

Basta atentar para um fato comum na época, em que essa prática da expedição científica constituía um dos pré-requisitos do saber descritivo. A coleta de material, istoé, das espécies exóticas do mundo novo, parecia ser uma técnica profícua de documentação do que, até então, mantivera-se intacto à sondagem perscrutadora da ciência. Porém, o rigor científico não se resumia à atividade da coleta. A classificação e a conservação das espécies exóticas nos jardins e nas estufas da Europa representavam etapa final do exercício de investigação difundido pelas viagens. Isso porque, de posse das amostras ou dos dados do Novo Mundo, reproduziam-se, na pátria do viajante, resquícios de imagem fiel, que não era senão a existência fictícia do seu conteúdo diferente. Porque o grau de diferença do Novo Mundo era medido pelos padrões de exótico da Europa, que ainda assim transportava essas amostras como fontes diretas do desconhecido.

Veremos mais adiante a ligação entre os esforços da pintura paisagística e a tentativa dos cientistas em teorizar sobre a transposição do meio físico e orgânico e sobre a adaptação de espécies vegetais em ecossistema diverso dos seus. Isso nos levará a conjeturar acerca dos conceitos utilizados para constituir a paisagem humboldtiana, ou seja, das unidades operacionais, como: fisionomia, conjunto, planta social, relação, etc. Nos certificaremos, a partir daí, como Humboldt tende cada vez mais a abandonar os grupos isolados a fim de dominá-los e introduzi-los em composições paisagísticas. Dentro desse seu procedimento, ele reconstrói os pequenos esboços de espécies individualizadas, com a finalidade de compor paisagens ideais.

\section{O OLHAR DE SOBREVÔO E 0 OLHAR TÁTIL}

Dirigido ao cultivo estético das cenas da natureza, o viajante potencializa toda a força de sua vista para tornar visível, claro e exato qualquer efeito de turvação que se possa misturar ao êxtase provocado pelo contato da beleza natural. Assim, o viajante, certeiro, segue perseguindo as margens, subindo as montanhas até ultrapassar todos os obstáculos para avistar o horizonte, a linha reta que descansa o olhar. Posto que os olhos fizessem movimentação para perscrutar, sondar e penetrar no desconhecido, a mente os acompanhava. Ela era sua fiel companheira, mas podia algumas vezes se precipitar e se arrojar a tornar fixo um aspecto que se apresentava à vista. Quando ela se precipita, ou se arroja, aquele olhar ganha corpo, ganha sentido através de uma idéia e aí o que se dá a ver não é somente o puro real, mas o real acrescido de conteúdo científico - do predeterminado do real. Nessa equação, olhare mente trocam idéias, 
sensações cuja visibilidade vai depender do veredicto final da ciência, vai depender do contorno pelo qual elas serão enquadradas. O olhar embeleza a idéia disposta com antecedência na mente do viajante e a mente organiza os sentidos. Há como que uma espacialização do olhar apoiada na disposição profissional do cientista em atentar para os sons, os sabores e os odores e, ao mesmo tempo, em abstrair e contemplar "as forças orgânicas em movimento" (11).

Numa análise detida do encontro de Humboldt com o mundo novo, comecemos por perseguir seu olhar diagnosticador e, com isso, a maneira apurada de conhecer através do estabelecimento de "quadros". Destaquemos a primeira descrição do Novo Mundo, tirada do início de Quadros, para compreender como se dará a primeira tentativa de julgar essa terra ignota que se oferece ao deciframento do europeu:

"Junto das altas montanhas que desafiaram a erupção das águas, ao formar-se, na mocidade da Terra, o mar das Antilhas, começa uma vasta planície que se estende até se perder de vista. Se, depois de atravessar os vales de Caracas e o lago de Tacarígua [...], se passar pelos prados onde brilha a verdura clara e suave das canas de açúcar de Taiti, ou se deixar para trás a sombra densa dos bosquezinhos de cacau, a vista dilata-se e descansa para o sul sobre estepes as quais parecem ir-se levantando gradualmente e desvanecer-se no horizonte.

Arrebatado, de súbito, a todas as riquezas da vida orgânica, o viajante fica surpreendido ao penetrar nesses espaços sem árvores, que mostram apenas indícios de vegetação. Nem uma colina, nem uma rocha sequer que se destaque, como uma ilha, no fundo da planície sem limites. Apenas algumas camadas horizontais se levantam rotas aqui e ali sobre o solo que as rodeia, e cobrem superfícies de quinhentas léguas quadradas. Os naturais do país chamam bancos a essas camadas, o antigo estado de coisas, naquele tempo em que essas estepes eram o leito de um vasto mar interior, cujos baixios seriam tais eminências" (12).
Se julgarmos a descrição acima como figuração de determinada forma de inquirir a natureza, isto é, como quadros figurativos de duas paisagens, devemos diferenciar o duplo suporte sobre o qual o olhar lançou mão de suas imagens. Num primeiro plano, que corresponderia a um primeiro suporte desse olhar, podemos vislumbrar a paisagem dilatada pela vista.

Avistada de longe e do alto, a imensidão da planície se refaz a cada golpe de vista a fim de esticar, a cada vez, o limite do olhar, até desaparecer ou "se perder de vista" no ilimitado desse prisma. O olhar continua a pairar numa espécie de sobrevôo da planície vasta e, assim, pode identificar os vales, cujas margens parecem sombreadas, a claridade, a suavidade da vegetação dos prados e a densa concentração de árvores de cacau. Discriminado cada um desses pontos, seus tipos de plantação e o efeito chiaroscuro que condensam, o olhar, motivado por diversa força, levanta-se gradualmente em direção ao ponto firme, estático do horizonte-porto propício ao descanso do olhar. Aqui termina o trajeto de sobrevôo que equilibra os vários aspectos e fixa o conjunto numa forma ajustada pela empunhada firme do olhar. A paisagem que nasceu daí é resultado de uma previsão abstrata da construção do "quadro". Tomada a distância, o observador dimensiona, sem nenhuma perspectiva tátil, o que permanece além dos tipos pitorescos dessa região em particular.

O mesmo horizonte, servindo de porto aprazível para o olhar, serve também de ponto de mutação por onde se inflete o olhar em direção a outra forma de apreciação. Aquele olhar arrebatador (13) - o olhar de sobrevôo -, que havia vislumbrado "todas as riquezas da vida orgânica", é substituído pela visão penetrante, apertada, que tateia, que prova o que está ao seu redor. Fincados os pés e as mãos sobre tal terreno, o viajante, surpreendido, se prepara para rastear alguns sinais de sua futura investigação. Rebaixado das alturas, ele se posiciona diante de tal paisagem a fim de escalar e penetrar a horizontalidade de outro espaço paisagístico. No contato direto com ele, o
11 Humboldt (1808), op cit, vol. 2, pp. 268 e 270: "Eram mai de onze horas quando comecou no bosque imediato um barutho tal que foi preciso re nunciar em absoluto a dormi durante o resto da noite. Todo mato ressoava com os gritos selvagens.[...] Eram os vivos guturais e monótonos dos aluatos: a voz queixosa aflautada dos tities, e os roncos do macaco dorminhoco (Nyctipithecus trivirgatus), cuja descrição dei em primeiro gar; os gritos entrecortados do grande tigre da América, do cuguardo ou leão sem juba do pecari, da preguiça e de um enxame de periquitos, os de parraquas (Ortalida ) e de outros galináceos. [ . . ] Tudo anuncia um mundo de força orgânicas em movimento. Em cada matagal, na casca gre tada das árvores e na terra que cavam os heminópteros, a vida agita-se e faz-se ouvir, como uma das mil vozes que a nat reza envia à alma piedosa sensivel do homem".

12 Humboldt(1808), op. cit., p. 5

3 ldem, ibidem, vol. 1, p. 186 É interessante o desconcerto provocado em Humboldt quando vislumbra a planície que, diferença da Europa, apresenta enorme vastidão e deserto: "Choca-nos [...] o aspecto da estepe tanto mais quanto mais tempo tenhamos permanecid na espessura dos bosques, acostumados a um horizonte pouco extenso e à vista de uma natureza ricamente ataviada. Da minha memória jamais se apagará a impressão que me causaram os plainos, quando depois de ter explorado a par e superior do Orenoco, tornei a vê-los, a grande distância do alto de uma montanha [...]. 
14 Idem, ibidem, p. 188. "Na margens do Orenoco, próximo de Caicara, junto do sítio onde a região do bosque confina com a planície, encontramos, com certeza, imagens do sol tiguras de animais, gravadas nas pedras; mas, nos próprio plainos, nunca se descobriu vestígio algum desta índole, por grosseira que fosse, que ates asse a existência de habitantes anteriores". Outra passagem que se segue reafirma o esto ço de Humboldt para explica o despovoamento e o aspecto intacto da América Meridional onde o único interesse do cientista deve se restringir à nature za: "[...] apesar de que as esepes da América Meridiona estão cobertas de uma leve camada de terra vegetal, são regadas por ondas periódicas e vestem-se, como por encanto, com um rico tapete de verdura, nunca puderam chama a si as povoações limítrofes decidi-las a deixar os formosos vales de Caracas, as margens do mar e esse mundo de rios que formam a bacia do Orenoco, para irem perder-se em desertos desprovidos de árvores e mananciais" (p. 16)

15 Idem, ibidem, vol.2, p. 258

16 ldem, ibidem, p. 275. "Os tipos que tendem a desaparece deixam vazios, porque se vão reduzindo a um número decres cente de individuos, enquanto que os que devem substituí-los são, a princípio, obscuros, de traços mal delineados, e disseminados aqui e ali'

17 ldem, ibidem, vol. 1 p. 10 "Os plainos, com efeito, não são habitáveis senão para animais; e, sem dúvida, não teriam podido reter hordas nômades, que gostam, como os índios, de a limento vegetal, se não estivessem esparsas aqui e al as palmeiras leques[...]" 18). "A vida pastoril, transição feliz que assenta hordas de caçadores nômades sobre um solo fértil em pastos, e as pre para para a agricultura, ficou, pois, ignorada das povoações primitivas da América. A essa ignorância deve ser atribuída viajante constata: ali, a terra é de ninguém. Para ele, a vida ali de tal forma se desorganizou que só restaram os “indícios de vegetação”, os “espaços sem árvores"; "nem uma colina, nem uma rocha sequer", nada é agente desse lugar "sem limites". O que ele verifica é a presença de indícios, os sinais de ausência de uma vida orgânica de outro tempo, de um "antigo estado de coisas" - talvez, de um tempo originário.

Os elementos dessa segunda paisagem incomodam estranhamente o cientista. Equilibrado pelo olhar de sobrevôo, ele, agora, sente-se atormentado pelo aspecto de deserto da planície - pela ausência de conhecido - e seus traços de ruína, que tenta a todo esforço negar (14). Onde mora o elemento perturbador? Certamente nos sinais, nos vestígios: "estes vestígios [...] são confusos, e todos os observadores que os analisam, ainda aqueles que são mais instruídos, têm, no começo das suas investigações, algum trabalho para lhes compreender o sentido" (15). Isso porque o que incomoda nos "indícios de vegetação" e nas "tais eminências" é o fato de eles estarem no limite entre o limiar da vida e o desaparecimento (16) - entre a superfície de quinhentas léguas quadradas "sem árvores", sem rocha e sem colina e o antigo "vasto mar interior” -, que é o próprio limite entre a justificação científica e o mistério improvável ou ainda entre uma história possível e a unidade espacial.

A aura de mistério revestindo a imagem de ilusão visualizada pelo viajante não dura muito tempo. A mente permanece sob vigília, cada vez mais acesa, impedindo o livre vôo da imaginação. O olhar presta-se como uma sentinela pois guarda com segurança o absoluto da visão. Assim, a ciência de Humboldt encontra-se poderosamente armada contra qualquer hipótese e interpretação que considere provável, a partir dos indícios, a existência de "antigos povoadores" ou "raças extintas" naquele terreno: "Nenhum oásis lembra a morada de antigos povoadores; nem uma pedra lavrada, nem árvore algu- ma que afirmem a atividade de raças extintas. Estranho, por assim dizer, aos destinos da humanidade, e ligado apenas ao momento que passa, este canto da terra parece um teatro selvagem, onde se exibe livremente a vida dos animais e das plantas" (17). A terra americana é desse modo um lugar que se define pelo movimento de espacialização de animais e plantas.

E a ciência de Humboldt é um saber que, passando por cima dos indícios, não pretende formar uma genealogia sobre a terra americana e nem dar contar desse tempo originário que não cabe em uma história teleológica. Ela somente procura explicar o desenvolvimento da "vida orgânica" num lugar e num espaço (talvez) inconcluso em que a cultura européia se espelha e se inclui. E tudo, nesse terreno, que não seja explicável ou esperável dentro de uma medida evolucionista parece ameaçar a escalada do progresso. Os vestígios levam à dúvida ou a hipóteses não atestáveis. Eles não só podem entrever delineamentos confusos, aparentemente indecifráveis para o naturalista - o calcanhar-de-aquiles da ciência - como, para nós, servirão para indicar o ponto decisivo pelo qual se opera uma mudança na atitude do cientista - e aí, ele tem de abdicar da observação essencialmente empírica, visual, para resgatar as condições determinantes daquela aparência de ruína, mesmo que para is so seja necessário negar o que ele constata visualmente. Vejamos como, ao conceber o vestígio como forma de enigma, se dá essa mudança:

“E, não obstante, esses enigmas, cuja solução é difícil, representam as frases esparsas do velho livro da natureza. Se, por acaso, háobstinação emos decifrar, esquece-se bem depressa a natureza singular dos caracteres e o mau estado das páginas que nos impressionaram. O pensamento eleva-se a grandes alturas, todas as idéias tomam maior desenvolvimento, ampliam-se e desenrolam-se fastos da crônica; neste momentoé o túmulo, e que o gênero de túmulo! o único que fala e que deixa escapar o seu segredo. O natu- 
ralista, ainda o mais modesto, pode às vezes operar estas verdadeiras maravilhas; e acha, na observação de um fragmento que na aparência é informe, no exame de um qualquer órgão isolado, uma folha, por exemplo, cujo conhecimento the permite a reconstrução perfeita de todo vegetal de que esse fragmento fazia parte" (18).

Como, então, o viajante entende esse cenário do "novo continente" que, para ele, não tem história e apresenta o aspecto único da natureza, mas que, necessariamente, o remete a um passado remoto? Será que a simples presença de vestígios obriga a uma investigação científica leitora dos dados além da aparência sensível, ou que a própria ausência de forma inteira explicitada do vestígio obriga o cientista a ler nas entrelinhas do "velho livro da natureza" o aparentemente indecifrável? Será que, se não houvesse os vestígios, a observação de Humboldt se resumiria ao método descritivo da imagem visual? A única orientação possível para responder a essas indagações parte do que já afirmávamos no início deste capítulo: em Humboldt existe uma simultaneidade entre duas formas de conhecer - que, por sua vez, se desdobram na dupla disposição do olhar. Aquela que é resultado da experiência visual do viajante e aquela cuja dedução de uma lei, a partir do dado observado, pressupõe um conhecimento prévio à aparência, esquecendo "a natureza singular dos caracteres".

O que podemos julgar interessante até aqui é como a constatação e a imediata negação do vestígio são condicionadas em função do impasse que ele cria para a ciência. Este impasse, por sua vez, faz com que Humboldt abandone - e, com is so, negue sem destruir - a medida visual para o conhecimento da paisagem americana, adotando uma qualificação invisível do fenômeno. Deixemos, por enquanto, essas questões sobre o estatuto da ciência do XIX e a natureza instável do vestígio e vejamos a reação primeira do viajante, quando depara com as espécies de resíduos.

\section{OS ASPECTOS DE RUÍNA E A "SEDE DA GAZELA" (19)}

A primeira forma de se aproximar desse cenário com marcas antigas - onde as estepes eram outrora "o leito de um vasto mar interior" - é pelo resgate dessa imagem por meio da "ilusão dos sentidos". A incerteza despertada pela presença de vestígios leva o cientista à miragem:

"Hoje, contudo, ao chegar da noite, recordamos, por uma ilusão dos sentidos, aquelas imagens de um tempo que passou. Quando o extremo da planície se ilumina com o rápido nascimento ou ocaso dos astros brilhantes, ou a luz trêmula destes se reflecte sobre as camadas inferiores dos vapores ondulantes, julgamos ter diante dos olhos um oceano imenso. Como este, as charnecas enchem também a alma com o sentimento do infinito, desligam-na das impressões materiais que produzem os espaços limitados, e elevam-na mais altas aspirações. Mas tão suave é a contemplação do claro espelho do mar, encrespado pela ondas inquietas e espumantes, como fria e morta a perspectiva do deserto, semelhante à que apresentaria a crosta escalvada de um planeta devastado"(20).

Essa passagem descreve a miragem como resultado de um efeito ótico experimentado por Humboldt logo após seu encontro com os elementos da segunda paisagem, que, para serem percebidas, exigia o emprego do olhar tátil. O curioso na descrição dessa imagem ilusória é que, diante dos aspectos de ruína notados na observação direta, a suspensão do impulso objetivador de Humboldt passa a ser necessária: diante da aparência "informe", detectada pelo interesse puramente concreto-visual, tornase necessário domesticar a ilusão pela via da especulação. "O naturalista”, diz Humboldt, “[...] pode às vezes operar [...] verdadeiras maravilhas; e acha, na observação de um fragmento que na aparência é informe [...] uma folha, por exemplo, cujo a falta de todo o gênero de população nas estepes da América Meridional. As diversas espécies de animais que as habitam nelas se desenvoveram com tanto maior ene gia. Nada embaraçava, com efeito, a sua liberdade natu ral; só elas podiam ser obstá culos a si próprias. Acontecia com a vida animal o mesmo que com o vegetal nos bosques que cercam o Orenoco, onde os hymenoea e o loureiro de tronco gigantesco jamais são destruídos, na verdade, pela mão do homem, mas pode bem morrer afogados pela pressão das plantas trepade as que os enlaçam".

18 ldem, ibidem, vol.2, p. 259

191 dem, ibidem, p. 193. "O fe nômeno conhecidíssimo da miragem é chamado em sânscrito, a sede de gazela".

20 ldem, ibidem, p. 6 . 
21 Ver citação destacada nas pp. $13-4$

22 Humboldt (1808), op. cit., p 193. Naquilo que se chama parte científica do livro, Humboldt vai explicar com detalhes o fenômeno da miragem: "Todos os objetos parecem Hlutuar no ar, em cuja camada inferior se refletem. deserto semelha um mar sem limites, cuja superfície esteja ag tada pelas ondas. No horizonte aparecem, invertidos, troncos de palmeiras, bois e camelos. Du rante a expedição dos france ses ao Egito, essa ilusão óptica desesperou em extremo e com freqüência os soldados. Este fenômeno produz-se em todas a partes da terra. Os antigos conheciam também os efeitos singulares da refracção da luz no deserto da Líbia. Estas imagen enganadoras acham-se mencionadas em Diodoro de Sicília com explicações muito aventu radas acerca da condensação do $\mathrm{ar}^{\prime \prime}$

23 Idem, ibidem, vol. 2, p. 261 "Pode dizer-se que um vestígio vegetal não é outra coisa senão um molde das partes exteriores de uma planta, o qual formado por uma matéria plástica aplicada, em primeiro lugar, contra as desigualdades existentes no original e mais tarde consolidada. Os mesmos fatos se passam quando o homem molda um objeto qualquer: divergindo apenas em que a natureza obteve os fins a que se dirigia empregando meios que são ao mesmo tempo mais lentos e mais seguros: produzindo com estes meios, resultados cui delicadeza excede em muito das obras humanas." conhecimento lhe permite a reconstrução perfeita de todo vegetal de que seu fragmento fazia parte" (21).

Há de se considerar também que, ao descrever essa passagem, Humboldt parecia consciente das causas que o levavam da surpresa à ilusão (22). O efeito ilusório então não conspira contra a sua ciência, ao invés, se reconcilia com ela, porque é habilmente trabalhado de maneira a não só reforçar a via transcendente para o conhecimento dessa realidade americana, mas a fazer com que se negue o vestígio como fonte de história, conhecimento e beleza.

O vestígio serve de algo ao cientista, ao menos enquanto estiver sendo controlado e reduzido seu poder de falseamento: como deleite puro, a princípio porque leva de imediato ao desligamento do real em prol da exploração de uma imagem ilusória - e, logo depois, como revitalizador do impulso cognitivo. Enche a "alma" do viajante "com o sentimento de infinito". Suspende os sentidos, "as impressões materiais que produzem os espaços limitados" para deixar o viajante se extasiar no deleite de suas imagens ilusórias. Acorda a memória, congela o tempo e faz da miragem veículo farejador daquele tempo inalcançável, onde a paisagem ganhava vulto espectral.

A pontuação do olhar segue-se logo após ao translúcido da paisagem-miragem como forma de escape do vestígio. Destinado a ordenar o juízo acerca do real, o olhar tátil - correlato ao segundo modo de inquirir a natureza - desorganiza a impressão, causa embaraço em Humboldt, porque através dele ele se depara com o aspecto informe dos vestígios (23). Ao contrário do olhar de sobrevôo que adia a diversidade e o aspecto individual dos vegetais, o olhar, o mais próximo da terra, constata na singularidade dos caracteres isolados a falta de unidade e, por isso, precisa lançar-se ao sobrevôo especulativo em busca de estabilidade. Assim, Humboldt termina por escapar da direção do olhar tátil para bajular o espírito com recordações amenas.

\section{A CIÊNCIA E O VEREDICTO FINAL}

Apontemos algumas conclusões acerca do movimento de espacialização do olhar de Humboldt. A situação de vestígio, caracterizadora daquele deserto, apresenta-se, de início, aquém do campo determinável da ciência de Humboldt e, portanto, propícia à visualização de paisagens-miragem. A posteriori, essa situação de vestígio torna-se aceitável única e exclusivamente porque é capaz de provocar o "fenômeno conhecidíssimo da miragem". A miragem perde seu caráter ilusório em função da explicação científica que a define segundo combinação entre a densidade de luz e sua capacidade de reflexão numa superfície. Desse modo, é restituída a confiança naquilo que há pouco era fruto da pura "ilusão dos sentidos" e a miragem é finalmente domada pelo seu próprio significado científico.

É notável ainda que o afã cientificista de Humboldt suplante alguns restos do desconhecido através do movimento de construção e imediata dissolução da miragem. O vestígio é suplantado pelo poder de reconstituição intrínseco à explicação humboldtiana. Precisando e/ou aproximando o indício, o resto e o destroço de um conjunto ou de uma espécie inteira à constituição harmônica de um tempo primitivo:

"Fazendo o estudo dos restos vegetais que sejam retirados das entranhas da terra, onde, durante um número incalculável de séculos, tenham estado sepultados, pode a ciência geognóstica, por um método puramente sintético, reconstituir completamente o aspecto que apresentavam as diversas regiões da Europa nas diversas idades geológicas, e determinar, com precisão ou pelo menos aproximadamente, quais seriam as condições climatéricas das nossas regiões, bem como os animais que, em virtude dessas condições, nelas podiam existir e encontrar alimentação, conhecendo também quais as transformações por que têm passado os reinos animal e vegetal muito tempo 
antes da aparição do homem na superfície terrestre" (24).

Se os vestígios são os sinais da ruína e os sinais da ruína são restaurados pela miragem, sobreposta à paisagem real, então, há de se constatar a função reparadora, reconciliatória da imagem ilusória. É por meio dela que se pretende restabelecer e recuperar, "das entranhas da terra", uma situação histórica vivida anteriormente e suscitada de um "estado sepultado". Ela ainda serve para resgatar o que a ação do tempo destruiu, tornando possível a volta a um estado primitivo sempre perfeito e intacto. Ela infinitiza o tempo. É a imagem da infinitude poética, da busca do sentimento humano pela beleza e solidez da natureza.

Mas habilitemo-nos a considerar que, a despeito da simultaneidade pacífica entre efeito ilusório e conhecimento objetivo, pretendida por Humboldt no processo de visualização de paisagens, a incompatibilidade inata entre os dois determinará a função moral e pragmática da imagemmiragem configurada aqui. Sendo a ciência incompatível com a ilusão, porque necessita dos contornos claros, ela vai impor à ilusão uma explicação científica, que a torna domesticada. E a ilusão que, por sua vez, é incompatível com a ciência, pois depende da ativação da faculdade imaginativa, vai ter seu efeito, nocivo para a ciência, amenizado. Assim, a ciência de Humboldt toma as rédeas do percurso e domestica a ilusão, fazendo dela uma função preparatória do conhecimento e compensatória para as "almas melancólicas". Lembre-se aqui a citação acima destacada Nela, Humboldt descreve a miragem vislumbrada junto à planície desértica. Ela é bastante esclarecedora desse papel preparatório e compensatório desempenhado pela impressão da imagem ilusória na imaginação do homem: "as charnecas enchem também a alma com o sentimento do infinito, desligam-na das impressões materiais que produzem os espaços limitados, e elevamna a mais altas aspirações".

Por este traçado, justifica-se a necessi- dade do movimento de construção e dissolução da miragem pela ciência. Nele, a miragem é dissolvida com o objetivo de restituir o movimento anterior à ruína - a origem ou o estado originário da natureza - com base nos conhecimentos científicos. Daí as hipóteses sobre a existência de um "vasto mar interior": "não resta dúvida de que, em outra época, o mar cobriu toda a cavidade". Desse modo o que se avista a partir da miragem é o mesmo veredicto final do cientista. Miragem e hipótese científica se congraçam. É como se houvesse sempre um fundamento científico para respaldar a impressão causada pelo olhar tátil. Essa foi a forma encontrada por Humboldt para legitimar a miragem enquanto função compensatória: a própria ciência funcionando, via reconstituição de fragmentos ou vestígios, como propulsora de miragens.

Devemos terminar fazendo algumas considerações conclusivas e nos perguntar: será que aqueles que não tivessem o mesmo interesse científico de Humboldt saberiam distinguir com a mesma astúcia a paisagem-miragem da paisagem real? Nada nos garante que, para os "inexpertos" (25), esses indícios não seriam o prelúdio de uma imagem ilusória e fantástica, e que, justamente por ser ilusória e fantástica, seria essencialmente a paisagem desse "Novo Mundo", que fascinava o europeu. Para aqueles que não conhecem os detalhes ou não sabem supervisionar a distância o aspecto geral - ou seja, conformá-los aos grilhões da regra científica -, a miragem pode ser a própria imagem da paisagem americana prevista pelo europeu.

Para Humboldt, a expressão, usada pelos habitantes americanos para denominar as camadas horizontais presentes em tais estepes - no tempoem que elas possivelmente abarcavam um "vasto mar interior" -, era fruto ou do "acaso" ou do "pressentimento". E a vista dessas planícies sob determinada luz refletida poderia dar a ver ali um oceano imenso. Esta era uma visão, a princípio, puramente destituída dos sentidos, portanto, ilusória. A princípio, porque oque se julga ver diante dos olhos na paisagem-
24 Idem, ibidem, vol. 2, p. 258

25 Deve-se apontar aqui para a proximidade do raciocínio de Humboldt com o que dira Euclides logo no comeco da descrição da "Terra". Euclides preocupado em identificar as "três formações geognóstica díspares" que se configuram do extremo sul do litora paulista, passando por Minas, até a região do São Francisco, opta, apesar dos aspecto corrosivos que se agravam a proximidade do othar com a natureza, para a tendência de um aplainamento geral. Assim podemos verificar que, para Euclides, conforme distância e/ou proximidade que o ob servador alcança do solo natural que investiga, maior e/ou menor vai ser o efeito de ilusão e o efeito de verdadeiro. No seu caso, somente aqueles que se firmarem próximos da pasagem do sertão poderão per ceber os aspectos de ruína que caracterizam aquela natureza - "os restos da monstruos abóboda da antiga cordilheira, desabada" Se não vão segundo o autor, vislumbrar "as possantes massas graníiticas" como "paisagens admiráveis que tanto encantam e iludem as vistas inexpertas dos foras teiros" 
26 Humboldt (1808), op. cit., vol. 1. p. 185.

27 Talvez não seja mais preciso lembrar que a pintura de paisagem para Humboldté mais uma forma de articular a reunião pre endida entre arte e ciência, ponto de sua orientação sobre ela seguir claramente ainda impulso romântico de proporcionar, através da representação paisagística, o encontro da imaginação com o homem. "O grande estilo da pintura de paisagem é o truto da profunda contemplação da natureza e da transformação que se ve rifica no interior do pensamento [...]. Se a arte possui, toda via, um tanto a esperar, se me foi necessário indicar uma nova senda para volver, ao menos no pensamento, à antiga aliança da ciência, da arte, é preciso distinguir o elemento limitado que subministra a percep ção sensível, da ilimitada coheita que produzem uma profunda sensibilidade e uma imaginação poderosa. Graças a esta força criadora, a pintura de paisagem tomou um caráter que a transforma também numa espécie de poesia da natureza." Idem, ibidem, vol. 1, p 334

28 Estou me referindo ao Livro III e ao Livro IV do primeiro volume, cuios títulos seguem respectivamente: "Vida Nocturna dos An mais nas Florestas do Novo Mundo" e "Fisionomia das Plantas".

29 Humboldt (1808), op. cit. vol. 1, p. 260 miragem é justamente o que a ciência determinará como a presença ali de um "oceano imenso". Recordação de um período, vestígio de uma origem, essa imagem-miragem alimentava a "alma com o sentimento do infinito", desde que fosse colocada pacificamente ao lado da explicação científica, indicada de antemão nas notas. Ao "acaso ou pressentimento" dos "naturais do país" se contrapunha a dedução baseada nas certezas do europeu:

"[...] chamo golfo a esses plainos, porque, levando em conta a sua pouca elevação sobre o actual nível do mar e o seu aspecto particular, que parece dar acesso à corrente de rotação, dirigida de este para oeste, assim como a depressão das costas orientais [...], não resta dúvida de que, em outra época, o mar cobriu toda a cavidade [...] o solo dos plainos é tão uniforme que há, em muitos sítios, espaços de trinta milhas quadradas sem a mínima elevação. Levando em conta, além disso, a falta absoluta de árvores, sobretudo na Mesa dos Pavões, onde nem sequer há palmeiras espalhadas, poder-se-á fazer uma idéia do aspecto desta superfície deserta, que traz à memória o oceano” (26).

A ciência é a porta-voz do veredicto final, ela "não se limita a dizer que o ar é mais úmido numa parte do que em outra da Terra [...] O físico pode dispensar-se de ocultar sob mitos geológicos a explicação de semelhantes fenômenos". Há de se entender o caráter positivo que se acumula nas duas maneiras de observar a natureza. Tanto o olhar de sobrevôo quanto o olhar tátil são desmitificadores, ambos podem ser utilizados pela ciência embora um denegue o outro. O olhar a distância é responsável pelo deslumbramento que é positivo e necessário para que se examine de perto o caráter de cada região. A primeira forma de olhar, pela qual se experimenta esteticamente a cena da natureza, parece ser decisiva para incitar o observador a conhecer as causas responsáveis por determinadas peculiaridades de um solo. Ela é responsável pela impressão primeira e pela observação certeira do cientista.

\section{A PAISAGEM AMERICANA CONSTRUÍDA}

Se tivermos em conta que Quadros, dentro de seu comprometimento científico com a descrição de estruturas heterogêneas de vegetação, animais e terrenos, tendeu a compreender as forças da natureza e seus efeitos sobre a imaginação do homem e que, ao fazer isso, propiciou, dentre uma série de implicações, a constituição de alguns mecanismos para definir uma determinada noção de paisagem, talvez seja tempo de tentarmos identificar quais os elementos que, para Humboldt, formam uma composição paisagística (27).

No final do primeiro volume de $Q u a-$ dros encontramos Humboldt dedicando-se a tratar com sistematicidade os conceitos constitutivos da paisagem americana. É na parte reservada à descrição da vida animal do Novo Mundo e também na parte referente à fisionomia das plantas que eles serão tratados (28).

Conforme vamos avançando na leitura dessa parte, percebemos um cuidado especial para sublinhar expressões, explicá-las e defini-las no seu conteúdo, o que dá um caráter mais preciso ao texto. Não é de se estranhar, então, encontrarmos preocupação de Humboldt com a linguagem própria à descrição e com a adequação desta linguagem à "fisionomia" do real:

"[...] se a fisionomia das regiões habitadas pelos diversos povos [...] vem enriquecendo mais ou menos línguas com expressões pitorescas, próprias para caracterizar as formas da montanhas, o estado da ve getação, o aspecto da atmosfera, o contorno e agrupamento das nuvens, por outro lado o prolongadouso e os caprichos literários têm desviado grande número dessas expressões do seu primitivo significado" (29).

A preocupação com a linguagem da descrição e com a caracterização fisionômica de uma região através do modo descritivo poderia denotar um esforço ana- 
lítico por parte de Humboldt. No entanto, aqui, elas não se desenvolvem nesse sentido. A descrição humboldtiana nada tem a ver com a apreensão de uma diversidade complexificadora do discurso científico. Ela representa o meio divulgador da "expressão pitoresca” que está comprometido com uma forma dada, a forma científica de pitoresco.

A descrição científica da paisagem, neste caso, vem para fixar o contorno do pitoresco no interior de uma fisionomia ideal, que descarta a aparência paisagística. A paisagem do "pitoresco" é a representação mental de um conceito científico-poético de pitoresco, e interpretado, pelo cientista do século XIX, como o não-familiar mas cognoscível. Ele é necessariamente cognoscível, desde que embalado pela impressão e a primeira sensação produzida junto à paisagem americana.

Um dos primeiros elementos que salta aos olhos de Humboldt em seu contato com o Novo Mundo é o que ele chama de bosque primitivo. "A região florestal, que se estende na zona tórrida da América Meridional e preenche as duas bacias, unidas uma à outra, do Orenoco e do Amazonas, apresenta uma dessas grandes cenas da natureza. A região merece, na mais rigorosa acepção da palavra, o nome de bosque primitivo, do qual tanto se tem abusado em nossos dias" (30). O esforço de absolutizar o significado dessa expressão vem seguido de duras críticas às denominações vulgares difundidas sem o devido saber científico. Esse esforço vem acompanhado não só de duras críticas, mas, também, de uma tentativa de circunscrevere particularizar o lugar propício para a existência de tal bosque.

Disposto a procurar as condições - digamos ideais - destinadas a conformar dentro de uma paisagem ideal tal designação, só resta o Novo Mundo como meio apropriado para abarcar exclusivamente florestas virgens, impenetráveis e sem nenhum sinal da "mão destruidora do homem".

"Há-de chamar-se bosque primitivo ou floresta virgem a toda espécie de bosque espes- so e selvagem, cheio de vigorosas árvores, onde nunca chegou a mão destruidora do homem? [...] Se se quer sobretudo designar com ele a impenetrabilidade de uma vasta floresta, a impossibilidade de abrir-se caminho com o machado através de árvores que não medem menos de 3 ou 4 metros de diâmetro, as florestas virgens pertencem exclusivamente às regiões tropicais" (31).

A “impenetrabilidade" dos bosques tropicais representa, a princípio, antídoto contra os esforços não só da técnica de descrever, mas - o que livrava o viajante do trabalho insano de recolher e classificar as milhares de espécies diversas - do ato de conhecer e difundir, somente via descrição, a variedade da natureza exótica. Desse modo, ela favorece a introdução e o engajamento do olhar de sobrevôo especulativo, que lança mão daquilo que Humboldt vai chamar de "descrição geral". Descrição não mais da aparência paisagística ou de uma particularidade, mas de uma "forma essencial", que é geral. Pois até que se classifique, se descreva e particularize a infinita diversidade que compõe as florestas tropicais, o viajante se priva de divulgar numa forma incitante os traços caracterizadores dessa região: "Quaisquer que sejam a riqueza e flexibilidade de uma língua, não é todavia empresa sem dificuldades a de descrever [...] por meio de palavras [...] não falando na necessidade de se precaver contra a impressão monótona, que é a consequiência necessária de uma enumeração prolixa de objectos" (32).

Assim o teor da investigação científica da paisagem americana deixa de ser guiado pelo critério dos valores particulares e da variedade como dados últimos - que implicava o uso da descrição enquanto meio e fundamento objetivo para o cognitivo -, para ser orientado por nova equação, onde uniformidade encontra-se sobreposta à variedade, que não desaparece, mas sobrevive sob jugo. Aí “descrição geral”, “fisionomia" própria e "caráter nacional" de uma região formam os elementos diferenciais que, tomados em sua função domesticadora,
30 ldem, ibidem, vol. 1, p. 261

31 ldem, ibidem.

32 ldem, ibidem, p. 289 
vão servir para a composição e reconstituição de uma paisagem ideal.

E se na Europa, ou em qualquer outra parte do mundo, denomina-se bosque o conjunto de espécies compostas uniformemente, Humboldt parece lançar nova luz sobre o conhecimento que se tinha até então. Na Europa é costume, como diz ele, Pintura encontrar-se "espécies de árvores [que] hieroglifica tirada de manuscrito mexicano.

Conservada na biblioteca imperial de

Viena crescem em sociedade (plantae sociales)". Há os bosques de tílias, de carvalhos, que cobrem regiões inteiras sem se misturarem com qualquer outra espécie. Eles dão à paisagem européia um aspecto uniforme contrastante com as "famílias diversas" dispostas no bosque primitivo do Novo Mundo. E para que essas "famílias diversas" dos trópicos sejam pesquisadas pelo cientista terão de ser reunidas em grupos homogeneizadores que, pela semelhança

buscada, vão formar um todo.

Mas, afinal, como Humboldt irá construir essa paisagem do Novo Mundo? O modo descritivo de conhecer e construir fora descartado ou, ainda, sobrepujado. Aceitar a idéia de apresentar isoladamente cada espécie era o mesmo que concordar com uma forma expositiva "prolixa", vazia e "monótona" da ciência. Humboldt, de fato, parecia estar convencido de que a ciência precisava de uma forma amena, literária, que compensasse o discurso "árido" científico e que de alguma forma tocasse na imaginação do leitor. Para Humboldt, os elementos específicos e contrastantes do Novo Mundo poderiam embaraçar e ameaçar" "o ponto de vista europeu" (33), poderiam, ainda, atrapalhar a impressão dominante da invisível "força orgânica", pois o único interesse da pesquisa científica era

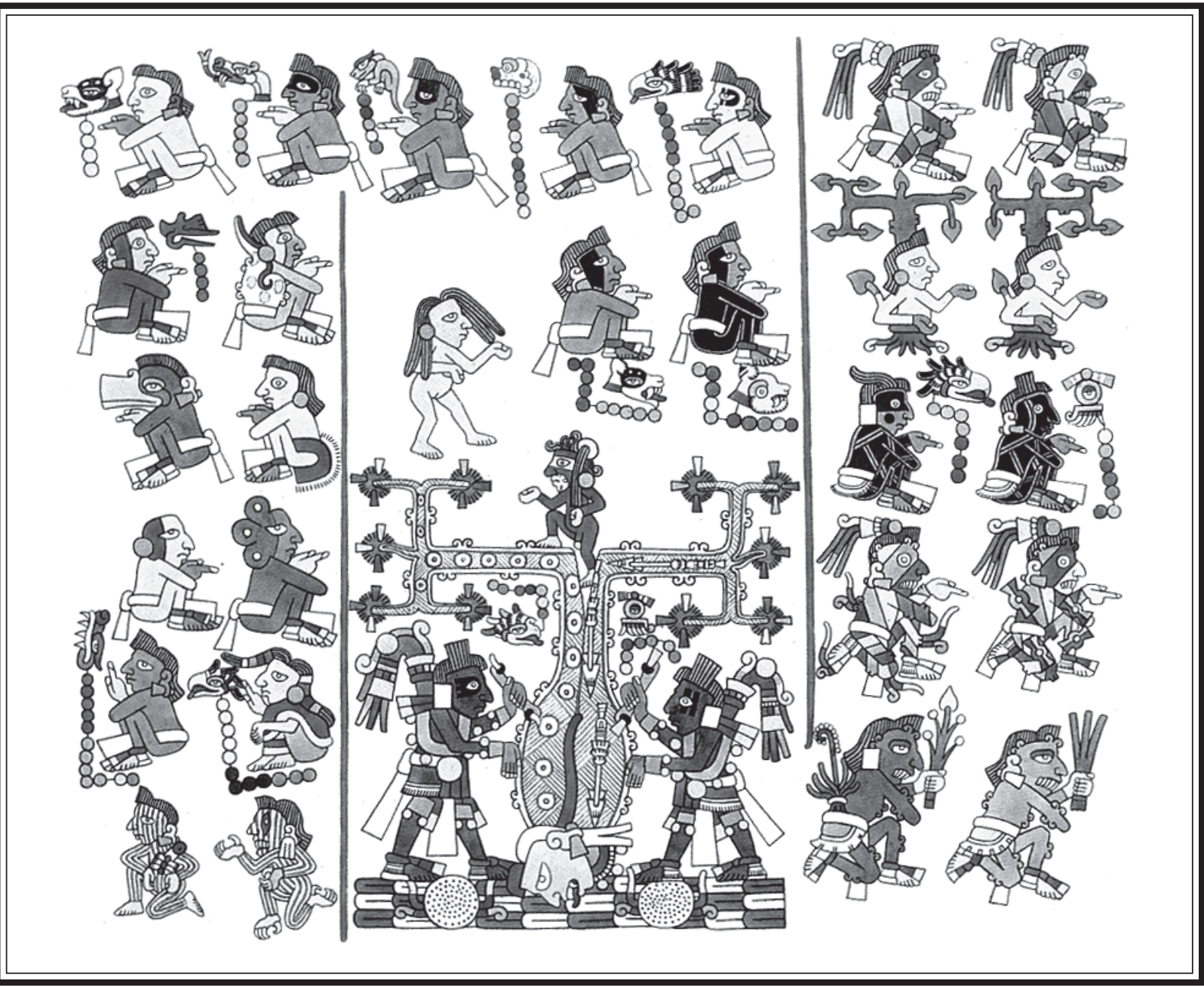


partir de um "ponto de vista muito elevado" para abstrair desses delineamentos singulares. A tomada de posição vem de uma sentença derradeira. A via especulativa parece ser a saída para construção da paisagem americana: "O homem, que sabe abraçar a natureza num só olhar e fazer abstração dos fenômenos particulares, reconhece como, à medida que o calor vivificante aumenta, se desenvolve gradualmente, dos pólos ao equador, a força orgânica e a potência vital" (34).

A construção da paisagem humboldtiana parece obedecer rigorosamente ao preceito de sua investigação científica. Humboldt reconhece a especificidade dos trópicos: "aos trópicos pertencem a magnitude e a variedade das formas vegetais; ao norte a vasta extensão das pradarias", desde que os tipos definidos distintivamente sejam subordinados a uma forma essencial. O reconhecimento, portanto, pressupõe o diferente domesticado por uma forma essencial aprioristicamente dada. Num golpe de vista, capta-se o conjunto, a massa imóvele magnífica. A diferença só pode ser realçada depois de minuciosa observação. O golpe de vista é homogeneizador, fixa somente aquilo que é investido de semelhança. É domesticador da diferença e do exótico.

Para entender melhor a tensão entre negação e suspensão do modo descritivo, na construção da paisagem humboldtiana, é importante considerarmos que ela deriva não só da busca de uma paisagem ideal mas também da "domesticação" da paisagem real como única forma de se aproximar do desconhecido. Assim, já estamos penetrando no solo explorado em Eternamente em Berço Esplêndido de Maria Helena Rouanet. Esta exploração se ocupará de distinguir a maneira pela qual a realidade americana no século XIX vai ser vista pelo europeu. E, para saber como ela era conhecida, é preciso, segundo a autora, identificar o segundo significado que a noção de exótico adquiriu com os relatos de viagem do Oitocentos:

“[...] o século XIX vai-se encarregar da criação de uma nova barreira protetora, que se ergue a partir mesmo do duplo sentido emprestado à palavra exótico. É preciso acrescentar, ainda, que, se a domesticação neutraliza ou afasta o que há de 'inquietante' nessa realidade tão 'estranha', nem por isto ela o destrói: este aspecto vai permanecer aí, como uma espécie de lençol d'água, permeando a atitude dos indivíduos que se relacionam com tal realidade" (35).

A construção da paisagem ideal representa mais uma tentativa de levantar essa "barreira protetora", convertendo a paisagem do Novo Mundo numa "realidade domesticada [que] vai constituir um quadro ameno, expresso pelo pitoresco e pela cor local, que servem tão bem à ‘exaltação das imaginações', especialmente numa época em que esses valores vão merecer destaque dentro do ideário romântico" (36). A paisagem real, que se constituiria a partir da pura observação imediata dos dados materiais, seria o exótico não-domado.

E a vantagem desse "num só olhar" de Humboldt, que "neutraliza ou afasta" a aparência vísível, é a facilidade que propicia ao não ter que se confrontar com o diverso e sua aparência exterior (37). O diverso nunca é antagônico; pelo contrário, é, desde logo, preparado para introduzir-se no conjunto uniformizado que, não obstante a presença de isolados tipos, possa no interior de uma "descrição geral" ser configurador de formas semelhantes. E essa forma semelhante, que vai configurar a paisagem humboldtiana, funda-se naquilo que Humboldt denomina de "massa vegetal". A massa concorre com o individual e, nesse sentido, elimina tudo que seja explicitado na aparência exterior. Ela equivale ao conjunto e à moldura fixa da ciência:

"Se o carácter das diversas regiões depende, ao mesmo tempo, de todas essas aparência exteriores; se o contorno dos montes, a fisionomia das plantas e dos animais, o azul dos céus, a forma das nuvens e a transparência da atmosfera concorrem para a impressão geral, não se pode negar,
33 M. H. Rouanet, "A Realidade Americana: o Ponto de Vista Europeu", in Eternamente em Berço Esplêndido, São Paulo Siciliano, 1991, p. 72 A a tora trabalha com a construção da realidade americana no XIX pelo ponto de vista europeu de modo a tornar claro como o conhecimento dessa realida de pressupunha uma domes icação: "para a Europa, ver América equivalia a domesticá la, através da adequação de uma rea lidade estranha aos pa râmetros do conhecido".

34 Humboldt (1808), op. cit., vol. 1, p. 283.

35 M. H. Rouanet, "A Realidade Americana: o Ponto de Vista Europeu", in op. cit., p. 73

$36 \mathrm{ldem}$, ibidem, p. 74

37 Humboldt (1808), vol. 1, p. 287. "Se se abracar num só olhar as diversas espécies de plantas fanerogâmicas que já iguram nos herbários, e cujo nu mero passa de oitenta mil, reco nhecem-se, no meio desta variedade infinita, algumas formas essenciais a que muitas outra se podem referir. Para determinar esses tipos, cuja beleza ind vidual, distribuição e agrupa mento decidem do caráter pró prio da vegetação de um país, não devemos guiar-nos, como por outras razões, se tem feito nas classificações botânicas pelos órgãos apenas visíveis da reproducão nem pelos invól cros florais ou frutos; mas sim pelos traços que sobressaem e determinam a impressão gera produzida pelas grandes mas sas vegetais" 
todavia, que os vegetais que cobrem a terra são a causa terminante dessa impressão" (38).

A introdução do conceito de massa é fundamental para que Humboldt consiga alinhar a paisagem do Novo Mundo aos desígnios de sua ciência. Por esse conceito, ele entende o que era considerado impenetrável ou desconhecido - a diversidade e o diferente.

Mesmo que sejamos capazes de identificar uma contradição latente no modo de constituir essa paisagem, devemos realçar a intersecção entre imagem poética e imagem científica que aqui se estabelece. A negação do modo descritivo aponta nessa direção, pois ele representa a saída para distinguir materialmente os dados experi- mentados, respeitando a formação diversa da organização tropical e articulando o particular com a explicitação das diferenças. Mas o efeito poético aponta noutra direção. Ele encontra a beleza no conjunto que submete os dados materiais à composição ideal. Assim, Humboldt sobrepõe a lente abstratizante da ciência especulativa à realidade americana que se apresenta debaixo de sua vista com a simples finalidade de legitimá-la. Esquecendo de uma vez o pormenor, as inúmeras diferenças presentes na aparência multiforme do Novo Mundo. Contudo, a paisagem de Humboldt deixa de ser uma superfície que faz conhecer uma realidade material particularizada da América para se tornar a representação da medida única dentro da qual a realidade americana é idealmente cognoscível. 